\title{
PENGGUNAAN TWO-TIER MULTIPLE CHOICE DIAGNOSTIC TEST DISERTAI CRIUNTUK MENGANALISIS MISKONSEPSI SISWA
}

\author{
Elvira Noprianti ${ }^{1}$ dan Lisa Utami ${ }^{1}$ \\ 1. Program Studi Pendidikan Kimia, Fakultas Tarbiyah dan Keguruan, Universitas Islam \\ Negeri Sultan Syarif Kasim Riau, Jl. HR. Subrantas Km. 15, Pekanbaru, 28293, Indonesia \\ E-mail: elviranoprianti30@gmail.com
}

\begin{abstract}
ABSTRAK
Penelitian ini merupakan penelitian deskriptif yang bertujuan untuk mendeskripsikan dan menjelaskan miskonsepsi yang dialami siswa pada materi larutan elektrolit dan konsep redoks serta menjelaskan faktorfaktor penyebab miskonsepsi siswa. Subyek penelitian adalah siswa kelas X SMAN 1 Tambang Tahun Ajaran 2016/2017. Sampel dipilih menggunakan teknik purposive sampling. Data miskonsepsi siswa diperoleh dari tes diagnostik, wawancara, dan kuisioner. Intrumen tes diagnostik two-tier multiple choice divalidasi isi dan konstruk oleh satu dosen ahli dan satu guru mata pelajaran kimia SMAN 1 Tambang serta divalidasi empirik oleh 25 siswa kelas XI IPA SMAN 1 Tambang. Hasil penelitian menunjukkan bahwa 10,63\% siswa mengalami miskonsepsi, 32,73\% siswa paham konsep, dan 56,64\% siswa tidak paham konsep. Miskonsepsi yang terjadi pada siswa disebabkan oleh kondisi siswa, buku pegangan dan guru.
\end{abstract}

Kata Kunci: tes diagnostik, miskonsepsi, two-tier multiple choice, CRI

\section{ABSTRACT}

This research was a descriptive research aiming at describing and explaining misconception encountered by student and factor causing students encountering misconceptions on electrolyte and redox concept. The research target is grade $X$ studentsin SMAN 1 Tambang. Purposive sampling technique was used. The technique of collecting of the data were using two-tier multiple choice diagnostic test combined with the Certainty of Response Index (CRI), distributing questionaire and interview. Instrument diagnostic two-tier multiple choice validated contents and constructs by one expert lecturer and one chemistry teacher and validated empiric for 25 students grade XI SMAN 1 Tambang. The research findings showed the percentage mean of student concept comprehension level that student understanding the concept were $32,73 \%$, student encountering misconception were 10,63\%, and students who did not understanding understand the concept were 56,64\%. Misconception happened to students was caused by the conditions of students, their handbooks, and teachers.

Keyword: diagnostic test, misconception, two-tier multiple choice, CRI

DOI: https://doi.org/10.15575/jtk.v2i2 


\section{PENDAHULUAN}

Miskonsepsi merupakan suatu pemahaman konsep yang tidak sesuai dengan konsep ilmiah. Berdasarkan teori konstruktivisme, miskonsepsi merupakan hasil dari konstruksi siswa yang didapat dari pengalaman, buku, guru, dan lingkungan (Suparno, 2013: 30). Miskonsepsi harus segera diidentifikasi dan diatasi. Jika dibiarkan, miskonsepsi dapat menghambat pemahaman siswa dalam memahami materi baru yang mengakibatkan prestasi dan hasil belajar siswa rendah, sehingga tujuan pembelajaran tidak tercapai (Suwarto, 2013: 76). Miskonsepsi dapat diidentifikasi menggunakan tes diagnostik. Tes diagnostik merupakan suatu tes yang dirancang khusus untuk mendiagnosis miskonsepsi siswa maupun kelemahan siswa dalam memahami konsep, sehingga dari hasil tes ini pendidik dapat merencanakan upayaupaya pemecahan sesuai dengan masalah atau kesulitan yang teridentifikasi (Depdiknas, 2007).

Salah satu tes diagnostik yang bisa digunakan untuk mengidentifikasi kesulitan siswa dalam memahami konsep adalah tes diagnostik twotier multiple choice. Two-tier multiple choice diagnostic test merupakan instrumen tes yang terdiri dari dua tingkat, tingkat pertama terdiri atas pertanyaan dan tingkat kedua terdiri atas pilihan alasan yang mengacu pada jawaban pada tingkat pertama (Tuysuz, 2009). Two-tier multiple choice memiliki kelebihan dibandingkan dengan multiple choice konvensional dan soal uraian, yaitu bisa mengurangi kesalahan dalam pengukuran dan dapat mengukur pemahaman pada level kognitif tinggi (Tuysuz, 2009). Akan tetapi twotier multiple choice ini memiliki kelemahan yaitu tidak selalu tepat dalam membedakan siswa yang paham konsep, tidak paham konsep, dengan siswa yang mengalami miskonsepsi, oleh karena itu dilakukan penyertaan teknik CRI (Certainty of Response Index). CRI merupakan teknik pengukuran tingkat keyakinan atau kepastian responden dalam menjawab setiap pertanyaan yang diberikan, sehingga pengukuran tingkat pemahaman siswa dapat terukur secara tepat (Mufida, 2016).

Berdasarkan diskusi pada 11 februari 2017 dengan salah satu guru kimia di SMAN 1 Tambang, menyatakan bahwa pemahaman konsep kimia siswa kelas X SMAN 1 Tambang termasuk dalam kategori rendah. Hal ini dibuktikan dengan rendahnya hasil belajar siswa pada ujian semester ganjil Tahun Ajaran 2016/2017. Untuk memperbaiki proses pembelajaran tersebut, perlu dilakukan penilaian yang bersifat diagnostik, artinya penilaian tersebut dapat digunakan untuk mengetahui kelemahan siswa (Arikunto, 2012).

\section{METODE PENELITIAN}

Penelitian ini merupakan penelitian deskriptif. Sampel dipilih menggunakan teknik purposive sampling. Intrumen tes diagnostik two-tier multiple choice yang digunakan telah dii validasi dan di konstruk oleh satu dosen ahlii dan satu guru mata pelajaran kimia SMAN 1 Tambang serta divalidasi empirik oleh 25 siswa kelas XI IPA SMAN 1 Tambang. Wawancara dan pemberian kuisioner dilakukan untuk mengetahui penyebab miskonsepsi siswa. wawancara dilakukan kapada siswa yang mengalami miskonsepsi. Kuisoner berisikan tentang pendapat siswa terhadap cara guru mengajar dan pengusaan konsep guru serta mengenai kelengkapan isi buku pegangan siswa. Berdasarkan tes diagnostik, diperoleh beberapa kemungkinan jawaban peserta didik dan kategorinya, dapat dilihat Tabel 1 . 
Tabel 1. Kemungkinan Pola Jawaban Peserta Didik dan Kategorinya.

\begin{tabular}{|c|c|c|c|}
\hline No & $\begin{array}{c}\text { Pola } \\
\text { Jawaban } \\
\text { Peserta } \\
\text { Didik }\end{array}$ & $\begin{array}{c}\text { Tingkat } \\
\text { Keyakinan }\end{array}$ & $\begin{array}{c}\text { Kategori } \\
\text { Tingkat } \\
\text { Pemahaman }\end{array}$ \\
\hline 1 & $\begin{array}{l}\text { Jawaban inti } \\
\text { tes benar- } \\
\text { alasan benar }\end{array}$ & $>2.5$ & Memahami (M) \\
\hline 2 & $\begin{array}{l}\text { Jawaban inti } \\
\text { tes benar- } \\
\text { alasan benar }\end{array}$ & $<2.5$ & Memahami (M) \\
\hline 3 & $\begin{array}{l}\text { Jawaban inti } \\
\text { tes benar- } \\
\text { alasan salah }\end{array}$ & $>2.5$ & $\begin{array}{l}\text { Miskonsepsi } \\
(\text { Mi-1) }\end{array}$ \\
\hline 4 & $\begin{array}{l}\text { Jawaban inti } \\
\text { tes benar- } \\
\text { alasan salah }\end{array}$ & $<2.5$ & $\begin{array}{l}\text { Tidak } \\
\text { Memahami } \\
(\mathrm{TM}-1)\end{array}$ \\
\hline 5 & $\begin{array}{l}\text { Jawaban inti } \\
\text { tes salah- } \\
\text { alasan benar }\end{array}$ & $>2.5$ & $\begin{array}{l}\text { Miskonsepsi } \\
(\text { Mi-2) }\end{array}$ \\
\hline 6 & $\begin{array}{l}\text { Jawaban inti } \\
\text { tes salah- } \\
\text { alasan benar }\end{array}$ & $<2.5$ & $\begin{array}{l}\text { Tidak } \\
\text { Memahami } \\
(\text { TM-2) }\end{array}$ \\
\hline 7 & $\begin{array}{l}\text { Jawaban inti } \\
\text { tes salah- } \\
\text { alasan salah }\end{array}$ & $>2.5$ & $\begin{array}{l}\text { Miskonsepsi } \\
(\mathrm{M}-3)\end{array}$ \\
\hline 8 & $\begin{array}{l}\text { Jawaban inti } \\
\text { tes salah- } \\
\text { alasan salah }\end{array}$ & $<2.5$ & $\begin{array}{l}\text { Tidak } \\
\text { Memahami } \\
\text { (TM-3) }\end{array}$ \\
\hline
\end{tabular}

(Nurhidayatullah, 2016)

\section{HASIL DAN PEMBAHASAN}

\subsection{Validasi Intrumen}

Instrumen tes diagnostik two-tier multiple choice yang dikembangkan berjumlah 28 butir soal. Pembuatan tes diagnostik two-tier multiple choice diadopsi dari penelitian yang dilakukan oleh Tuysuz yang mengembangkan two-tier test untuk mengidentifikasi miskonsepsi pada siswa yang terdiri dari beberapa tahap yaitu dimulai dengan kegiatan wawancara kepada responden kemudian memberikan pertanyaan dengan alasan terbuka, alasan yang diberikan responden akan dijadikan sebagai pengecoh pada pilihan alasan tingkat dua (Tuysuz, 2009). Berbeda dengan penelitian yang dilakukan Tuysuz, kegiatan wawancara akan diganti dengan pemberian tes essay kepada responden.

Berdasarkan validasi isi dan konstruk, soal yang dikembangkan layak digunakan untuk mendeteksi miskonsepsi siswa. Untuk validasi empirik, pengujian validitas intrumen digunakan rumus korelasi product moment. Dari 28 soal yang di ujikan, terdapat 11 soal yang tidak valid (soal nomor $3,7,8,11,12,15$, $19,22,24,25,27$ ) dan 17 soal yang valid (soal nomor 1, 2, 4, 5, 6, 9, 10, 13, 14, 16, 17, 18, 20). Dari 17 soal yang valid diambil 12 soal yang mewakili tiap indikator untuk diujikan ke sampel. Hal ini dilakukan untuk mempermudah tahap analisis data. Untuk reliabilitas intrumen digunakan rumus KR-20, didapatkan reliabilitas intrumen sebesar 0.83 dengan kriteria sangat tinggi.

\subsection{Pembahasan Miskonsepsi Siswa}

Berdasarkan hasil tes diagnostik diperoleh persentasi rata-rata tingkat pemahaman siswa yang ditunjukkan pada Gambar 1.

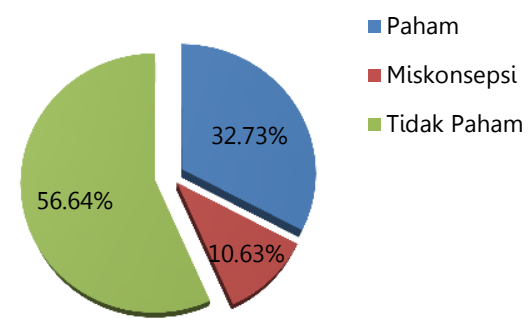

Gambar 1. Persentase Rata-rata Tingkat Pemahaman Siswa

Berdasarkan Gambar 1. dapat disimpulkan bahwa rata-rata siswa yang mengalamii miskonsepsi sebesar $10.63 \%$, paham konsep $32.73 \%$, dan tidak paham konsep sebesar 56.64\%. Persentase pemahaman siswa pada masing-masing soal disajikan pada Gambar 2 dan 3. 


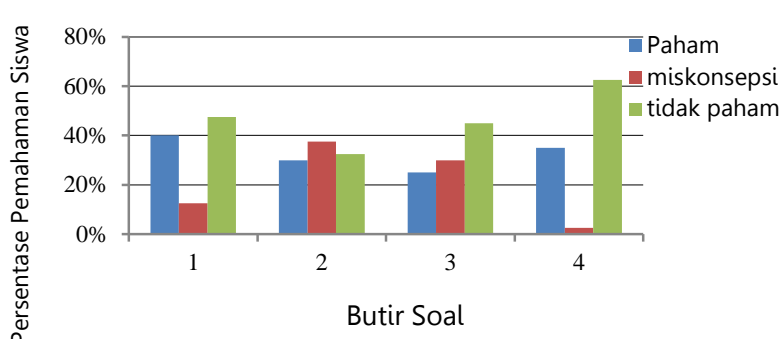

\section{Gambar 2. Persentase Pemahaman Siswa pada Materi Larutan Elektrolit}

Gambar 2. merupakan persentase pemahaman konsep siswa pada materi larutan elektrolit. Butir soal nomor 1, 2, dan 3 merupakan butir soal yang mewakili konsep pengelompokkan larutan elektrolit berdasarkan daya hantar listrik. Pada butir Soal 1, miskonsepsi siswa sebesar 12,5\%. Siswa beranggapan bahwa suatu larutan hanya bersifat elektrolit jika saat pengujian menghasilkan nyala lampu atau redup. Siswa tidak memperhatikan gejala lain yang terjadi seperti adanya gelembung gas. Pada butir soal nomor 2 persentase miskonsepsi sebesar 37,5\%. Butir ini membahas mengenai kemampuan larutan menghantarkan listrik dilihat dari konsentrasiya. Pada soal ini siswa yang mengalami miskonsepsi beranggapan bahwa semakin besar konsentrasi semakin baik daya hantar listriknya tanpa memperhatikan jenis larutan. Siswa menyatakan bahwa besarnya konsentrasi larutan sama dengan usaha yang kita lakukan. Semakin besar usaha semakin baik hasilnyMatal yang sama juga terjadi pada larutan semakin besar konsentrasi, semakin besar daya hantarnya. Pada soal Nomor 3 miskonsepsi siswa sebesar $30 \%$. Pada butir ini terdapat dua pola miskonsepsi. Pola pertama siswa beranggapan bahwa daya hantar listrik tergantung dari kelarutan suatu senyawa. Semakin mudah larut maka semakin baik daya hantarnya. Hal ini dikarenakan jika senyawa mudah larut maka akan banyak menghasilkan ion-ion didalam larutan sehingga larutan tersebut memiliki daya hantar listrik yang baik. Pola kedua siswa beranggapan bahwa $\mathrm{HCl}$ merupakan senyawa yang berikatan secara ionik, sehingga daya hantar $\mathrm{HCl}$ lebih baik dari pada daya hantar $\mathrm{H}_{3} \mathrm{PO}_{4}$. Kesalahan siswa dalam menentukan ikatan pada senyawa menandakan bahwa siswa memiliki pemahaman yang tidak lengkap pada materi ikatan kimia. Penemuan yang sama juga ditemukan oleh Wiwi Siswaningsih dimana siswa juga beranggapan bahwa $\mathrm{HCl}$ memberikan ion karena mengandung ion postitif dan ion negatif (Siswaningsih,2014). Pada butir soal nomor 4 miskonsepsi siswa sebesar 2,5\%, termasuk dalam kategori rendah. Soal ini membahas mengenai perbedaan daya hantar listrik senyawa ion dan kovalen. Pada soal ini siswa yang tidak paham konsep sebesar $62,5 \%$.

Dari keempat butir soal pada materi larutan elektrolit dapat disimpulkan bahwa persentase siswa yang tidak paham konsep lebih besar daripada siswa yang mengalami miskonsepsi. Pemahaman konsep siswa pada materi redoks dapat dilihat pada Gambar 3.

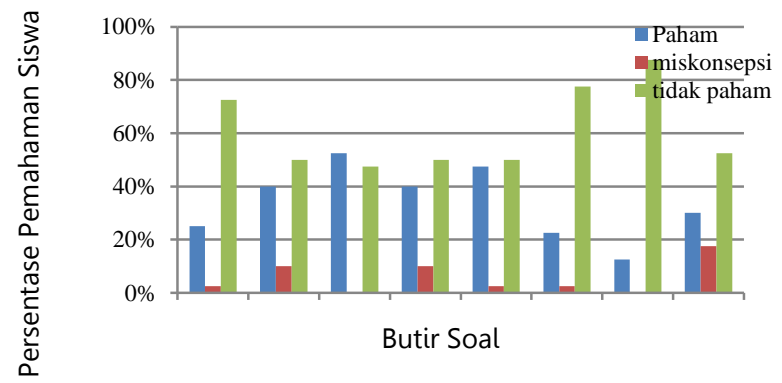

\section{Gambar 3. Persentase Pemahaman Siswa pada Redoks}

Gambar 3. merupakan persentase pemahaman siswa pada materi redoks. Miskonsepsi paling tinggi adalah pada soal nomor 12 membahas mengenai konsep tata nama berdasarkan IUPAC. Miskonsepsi pada soal ini sebesar $17,5 \%$. Siswa tidak bisa membedakan penamaan senyawa logam dengan senyawa kovalen. Siswa tidak memahami pemberian nama senyawa jika dikaitkan dengan bilangan oksidasi senyawa. Persentase miskonsepsi pada butir soal lainnya tergolong rendah, yaitu $10 \%$ pada butir soal 6 dan 7, yang membahas mengenai perkembangan konsep redoks dan penentuan oksidator dan reduktor dalam senyawa. 
Berdasarkan hasil wawancara yang dilakukan terhadap enam siswa yang mengalami miskonsepsi, miskonsepsi yang terjadi pada materi larutan elektrolit dan konsep redoks disebabkan oleh beberapa faktor yang bersumber dari siswa, guru dan Lembar Kerja Siswa (LKS). Adapun faktor terbesar yang menyebabkan miskonsepsi adalah siswa itu sendiri. Hal ini sesuai dengan pendapat ahli yang menyatakan bahwa miskonsepsi yang paling banyak berasal dari siswa (Suparno, 2013: 34). Penyebab miskonsepsi yang bersumber dari siswa adalah pemahaman yang tidak lengkap, rendahnya kemampuan siswa, kurangnya minat belajar siswa, dan pemikiran humanistik. Temuan adanya indikasi miskonsepsi siswa yang disebabkan oleh penalaran yang tidak lengkap, dan rendahnya kemampuan siswa sejalan dengan temuan Ferra Astuti yang menyatakan bahwa miskonsepsi yang berasal dari siswa adalah reasioning yang tidak lengkap, dan rendahnya kemampuan siswa (Ferra Astuti, 2016).

Selain wawancara, untuk mengungkap miskonsepsi siswa juga dilakukan penyebaran kuisioner. Kuisioner berisikan mengenai pendapat siswa terhadap penguasan konsep guru serta cara guru mengajar dan kelengkapan isi buku pegangan siswa. persentase pendapat siswa terhadap kuisioner disajikan pada Tabel 2.

Tabel 2. Respon Siswa terhadap Penguasaan Konsep Guru dan Kelengkapan Buku

\begin{tabular}{ccc}
\hline No $\begin{array}{c}\text { Pernyataan } \\
\text { Persentase Jawaban Siswa (\%) }\end{array}$ \\
\cline { 2 - 3 } & Ya & Tidak \\
\hline 1 & 91.42 & 8.58 \\
2 & 85.71 & 14.29 \\
3 & 82.35 & 17.65 \\
4 & 71.43 & 28.57 \\
5 & 42.86 & 57.14 \\
6 & 88.58 & 11.42 \\
7 & 5.27 & 94.28 \\
8 & 77.14 & 22.86 \\
9 & 74.28 & 25.72 \\
10 & 68.57 & 31.43 \\
\hline
\end{tabular}

Berdasarkan Tabel 2. siswa setuju bahwa guru menguasai materi pelajaran larutan elektrolit dan konsep redoks dengan baik. Penguasaan konsep yang baik oleh guru dapat meminimalisir terjadinya miskonsepsi. Namun penguasaan konsep yang baik oleh guru harus didukung dengan teknik yang tepat dalam meyampaikan pelajaran. $57.14 \%$ siswa manyatakan jika mereka tidak memahami penjelasan yang diberikan oleh guru. $77.14 \%$ siswa merasa kesulitan dalam memahamii materi yang ada dalam buku teks kimia, menurut siswa, hal ini dikarenakan bahasa didalam buku teks kimia tinggi, sehingga sulit untuk dipahami.

Berdasarkan hasil analisis angket, faktor penyebab miskonsepsi pada materi larutan elektrolit dan konsep redoks menurut siswa yaitu guru dan LKS. Penyebab miskonsepsi yang bersumber dari guru dan LKS sejalan dengan penelitian yang dilakukan oleh Luh Mentari yang mengungkapkan bahwa guru dan LKS bisa menjadi faktor penyebab miskonsepsi pada siswa (Luh Mentari, 2014). Miskonsepsi yang bersumber dari guru disebabkan oleh kurang menariknya cara guru menjelaskan pelajaran di kelas yang meneyebabkan minat siswa berkurang dalam mempelajari kimia. Sedangkan miskonsepsi yang berasal dari LKS disebabkan oleh kurang lengkapnya materi dalam LKS yang menyebabkan siswa memiliki pemahaman yang tidak utuh terhadap suatu konsep.

Guru menguasai materi larutan elektrolit dan larutan penyangga dengan baik, tetapi dari hasil wawancara, guru kurang menekankan penjelasan tentang sifat daya hantar senyawa ion dan senyawa kovalen, konsep penentuan oksidator dan reduktor, membedakan reaksi redoks dengan reaksi bukan redoks, tata nama berdasarkan IUPAC, sehingga siswa banyak yang tidak paham konsep dan miskonsepsi pada konsep ini.

Dari hasil tes diagnostik, wawancara dan kuisioner dapat disimpulkan bahwa miskonsepsi siswa di SMA Negeri 1 Tambang yang paling dominan berasal dari siswa itu sendiri, selain itu miskonsepsi juga bersumber dari guru dan LKS. Miskonsepsi yang 
bersumber dari siswa adalah kurangnya minat belajar siswa, pemikiran intuitif, rendahnya kemampuan siswa, dan pemikiran humanistik. Miskonsepsi yang bersumber dari guru berasal dari kurangnya penegasan guru terhadap materi pembelajaran dan kurang menariknya metode yang digunakan guru dalam menjelaskan pelajaran. Faktor miskonsepsi yang bersumber dari LKS adalah kurang lengkapnya materi dalam LKS, dan penggunaan bahasa yang sulit dipahami oleh siswa.

\section{KESIMPULAN}

Rata-rata persentase tingkat pemahaman konsep siswa kelas X SMA Negeri 1 Tambang pada materi larutan elektrolit dan konsep redoks adalah 32,73\% siswa paham konsep, $10,63 \%$ siswa mengalami miskonsepsi dan $56,64 \%$ siswa tidak paham konsep. Miskonsepsi yang dialami siswa disebabkan oleh kondisi siswa, LKS dan Guru.

\section{DAFTAR PUSTAKA}

Arikunto, S. (2012). Dasar-Dasar Evaluasi Pendidikan Edisi 2. Jakarta : Bumi Aksara

Departemen Pendidikan Nasional Direktorat Jendral Manajemen Pendidikan Dasar dan Menengah, Direktorat Pembinaan Sekolah Menengah Pertama Tahun 2007. Tes Diagnostik.

Ferra, A., Tri, R., \& Nanik D, N. (2016). Identifikaisi Miskonsepsi dan Penyebabnya pada Siswa Kelas XI MIA Negeri 1 Sukoharjo Tahun Pelajaran 2015/2016 pada Materi Pokok Stoikiometri.Jurnal Pendidikan Kimia Universitas Sebelas Maret, 5(2), ISSN 2337-9995, 10-17.

Luh. M., Nyoman S., \& Wayan S. (2014).Analisis Miskonsepsi Siswa SMA pada Pembelajaran Kimia untuk Materi Larutan Penyangga.E-journal Kimia
Visvitalis Universitas Pendidikan Ganesha, 2(1), 1-12.

Nofiana, M., Teguh, J.,\&Arum, A. (2016).Pengembangan Two-Tier Multiple Choice Question Disertai Teknik CRI Sebagai Intrumen Diagnostik Miskonsepsi Materi Genetika. Seminar Nasional Pendidikan dan Saintek. Universitas Muhamadiyah Gorontalo ISBN: 257-533X, 796-802.

Nurhidaytullah. (2016). Miskonsepsi Materi Larutan Penyangga pada Siswa di SMA Negeri 2 Mataram. Tesis. Fakultas MIPA : Universitas Negeri Yogyakarta.

Suparno, P. (2013). Miskonsepsi dan Perubahan Konsep dalam Pendidikan Fisika. Jakarta: PT. Gramedia Widiasarana Indonesia.

Suwarto. (2013). Pengembangan Tes Diagnostik dalam Pembelajaran, Panduan Praktis Bagi Pendidik dan Calon Pendidik. Yogyakarta: Pustaka Pelajar.

Tuysuz, C. (2009).Development of Two-tier Diagnostic Instrument and Assess Students Understanding in Chemistry.Academic Journal of Scientific Research and essay, 4(6) ISSN 1992$1248,626-631$.

Wiwi, S., Nur, A., Nur, E, K.,\& Indah R. (2014).Pengembangan Tes Diagnostik Two-tier untuk Mengidentifikasi Miskonsepsi pada Materi Kimia SMA. Jurnal pengajaran MIPA, 19(1), 117-127. 